\section{The place where you live and self-rated health in a large urban area}

\author{
O lugar onde se vive e a autoavaliação da saúde \\ em um grande centro urbano
}

\section{El lugar donde se vive y la autopercepción de la salud en un gran centro urbano}

\author{
1 Centro de Pesquisas René \\ Rachou, Fundação Oswaldo \\ Cruz, Belo Horizonte, Brasil. \\ 2 Instituto de Ciências Exatas, \\ Universidade Federal de \\ Minas Gerais, Belo Horizonte \\ Brasil. \\ 3 Faculdade da Saúde \\ e Ecologia Humana, \\ Vespasiano, Minas Gerais, \\ Brasil. \\ 4 Observatório de Saúde \\ Urbana de Belo Horizonte, \\ Belo Horizonte, Brasil. \\ 5 Faculdade de Medicina, \\ Universidade Federal de \\ Minas Gerais, Belo Horizonte, \\ Brasil. \\ Correspondence \\ D. E. Rodrigues \\ Centro de Pesquisas René \\ Rachou, Fundação \\ Oswaldo Cruz. \\ Av. Augusto de Lima 1715, \\ Belo Horizonte, $M G$ \\ 30190-002, Brasil. \\ daianaufmg@yahoo.com.br
}

\begin{abstract}
The aim of this study was to determine and quantify the association between one's perception of the place of residence and self-rated health. 4,048 adult residents of Belo Horizonte, Minas Gerais State, Brazil, participated in the study in 2008 and 2009. Ordinal logistic regression was used to estimate the magnitude of the association. Health was rated as good or very good, fair, or poor or very poor by $65.7 \%, 27.8 \%$, and $6.5 \%$ of the subjects, respectively. Better selfrated health was associated with the following neighborhood characteristics: positive evaluation of aesthetics and mobility, better quality of public services, less physical and social disorder. The perception of violence had a borderline statistically significant association with worse self-rated health. These associations persisted after controlling for potential confounding demographic, socioeconomic, health, and health behavior variables. The results indicate that public and health policies should incorporate interventions that address the physical and social environment in addition to policies focused on individuals.
\end{abstract}

Self-Assessment; Health Status; Spatial Perception; Urban Health

\author{
Daiana Elias Rodrigues 1 \\ Cibele Comini César 2 \\ César Coelho Xavier 3,4 \\ Waleska Teixeira Caiaffa 4,5 \\ Fernando Augusto Proietti 1,3
}

\section{Resumo}

O objetivo deste estudo foi determinar e quantificar a associação entre autopercepção do local de moradia e autoavaliação da saúde. Participaram da pesquisa 4.048 adultos residentes em Belo Horizonte, Minas Gerais, Brasil, de 2008 a 2009. Para estimar a magnitude das associações foi utilizada regressão logística ordinal. Autoavaliação da saúde boa/muito boa, razoável e ruim/muito ruim foi relatada por $65,7 \%, 27,8 \%$ e 6,5\% dos participantes, respectivamente. Melhor autoavaliação da saúde foi associada às seguintes características da vizinhança: avaliação positiva dos aspectos estéticos e da mobilidade, melhor qualidade dos serviços, menor desordem física e social. A percepção da violência apresentou associação estatística limítrofe com pior autoavaliação da saúde. As associações se mantiveram após o controle para potenciais variáveis de confusão demográficas, socioeconômicas, de condições de saúde e comportamentos em saúde. Os resultados indicam que políticas públicas e de saúde devem incorporar intervenções sobre o entorno físico e social em complemento às políticas individuais.

Autoavaliação; Nível de Saúde; Percepção Espacial; Saúde da População Urbana 


\section{Introduction}

Health should be understood in its physical, psychological and social dimensions. There are various strategies used to measure health. One important measure is the individual's own evaluation of his or her health ${ }^{1}$. Self-rated health is a global assessment of one's current state of health; it has been used in public health since the 1970s as it has been shown to be associated with morbidity and mortality 2 .

By asking: In general, how would you rate your health? - a question which most people can answer - it is possible to obtain information on the overall health of people, capturing subjective aspects that cannot be measured using health parameters considered objective $2,3,4$.

The great advantage of this simple question lies in the fact that it is a strong predictor of morbidity and mortality, even when one controls for chronic diseases, functional limitations, age, and other individual factors $5,6,7,8$.

Self-rated health is associated with individual and contextual variables 9. A number of studies report an association between self-rated health and the neighborhood's physical and social environment 10,11,12. Conceptually, the neighborhood should be understood in its physical and social dimensions as a place where people live and interact socially 13,14 . There are different strategies to characterize a neighborhood, such as using administrative units, systematic social observation, or a geographic information system 14,15,16. As used in this study, the individual's perception about the neighborhood is an alternative method that has the advantage of capturing information about particular attributes such as social cohesion, that are impossible to obtain with objective data 16,17 .

The way the physical and social environment is peceived is associated with self-rated health, regardless of individual and contextual measures 18,19 . Poortinga et al. 20 suggest that one's perception of their neighborhood has a mediating role on the association between an economically disadvantaged environment and poor selfrated health.

Few studies have been conducted in lowand middle-income countries that investigate the association between one's perception of the neighborhood and self-rated health. Using a representative sample of adults in the city of Belo Horizonte, Minas Gerais State, Brazil, the aim of this study was to determine and quantify the association between self-rated health and how the neighborhood's physical and social environment are perceived.

\section{Methodology}

\section{Population and source of data}

Belo Horizonte - with a population of $2,375,444$ according the 2010 census - is the capital of the State of Minas Gerais, which is located in Brazil's southeastern region. The BH Health Study study was conducted by the Belo Horizonte Observatory for Urban Health in 2008 and 200921.

Data collection was conducted in two of Belo Horizonte's nine public health districts, Barreiro and Oeste. Each has a population of about 250,000 inhabitants that is highly heterogeneous with regard to several demographic, socioeconomic and health indicators 21 .

The two health districts studied were subdivided into strata according to the health vulnerability index (HVI), a composite indicator developed by the Belo Horizonte Municipal Health Department as a summary measure which captures the inequalities in the epidemiological profile of distinct social groups within the census tracts, taking in account components such as sanitation, housing, education, income, and health 22 .

The sample was proportionally distributed across four strata defined by the HVI. Within each stratum, selection was carried out by a threestage probability sampling. In the first stage, 150 census tracts with different probabilities and a sample size proportional to the population of all tracts in the stratum were selected. In the second stage, 7,942 households were randomly selected from households registered in the Belo Horizonte city database. Finally, one adult resident (18 years or older) and one adolescent resident (11-17 years) were randomly selected from each household. Further details can be found in Camargos et al. 23 and Célio et al. ${ }^{24}$.

A total of 4,048 adults answered the faceto-face questionnaire conducted by trained interviewers. The questionnaire was comprised of six modules: household, sociodemographic, mobility, social determinants, health, and habits and behaviors.

The BH Health Study study was approved by the Ethics Research Committee of the Federal University of Minas Gerais (opinions ETCI 017/07 and ETCI 253/006). Participants were informed about the study's objectives and signed an informed consent form. 
Variables

\section{- Response variable}

Self-rated health was evaluated using the question: "In general, how would you rate your health?, with responses chosen from a five-category scale: "very good", "good", "fair", "poor", "very poor”. In this study, the responses were consolidated into three categories: very good/good (the reference category), fair, and poor/very poor.

\section{- Explanatory variables}

The variables chosen for this study were divided in the following modules:

a) Demographic: age in years; sex; marital status: single, married/living together, divorced/separated, widow(er); schooling: no schooling; able to $\mathrm{read} /$ primary school equivalency; 1 st- $4^{\text {th }}$ grades not completed; $1^{\text {st- }} 4^{\text {th }}$ grades completed; $5^{\text {th }}-8^{\text {th }}$ grades not completed; $5^{\text {th }}$ - ${ }^{\text {th }}$ grades completed; high school not completed; high school graduate/ technical school/attended university; university graduate; post-undergraduate studies; b) Socioeconomic: has private health insurance: yes/no; socioeconomic position score as detailed below;

c) Lifestyle and behaviors: smoking: current smoker, former smoker, never smoked; consumption of fruits and vegetables: defined by eating at least one portion five days a week during the past 12 months: yes/no;

d) Functional status: motor, visual or hearing limitation, difficulty or disability: yes/no. Pregnancy or temporary disability are not included;

e) Health status: body mass index defined as weight $(\mathrm{kg}) / \mathrm{height}\left(\mathrm{m}^{2}\right)$; chronic illness reported, as detailed below;

f) Years residing in the household;

g) Perception of the neighborhood, as detailed below.

For the socioeconomic position score the following 13 indicators were used: number of residents per bedroom; residence property title: rented, owned, borrowed, other. For the other indicators, responses were categorized as yes/ no: do you have a DVD, VCR; cable TV; microwave oven; washing machine; wash basin; motorcycle; newspaper and/or magazine subscription; computer; Internet access; car; and sleep-in maid/housekeeper.

The variable "self-reported chronic illnesses" considered the following diseases: hypertension, hypercholesterolemia, diabetes, asthma, arthritis, rheumatism, osteoporosis, arthrosis, chronic renal disease, depression, migraine, epilepsy, tuberculosis, cancer, heart disease, chronic disease of the lung (bronchitis, emphysema), chronic digestive disease (ulcer/ gastritis), mental illnesses (schizophrenia/psychosis/anxiety disorder/bipolar disorder/OCD/ panic disorders/anorexia/ bulimia). For the purposes of analysis, the variable was consolidated into three categories: no chronic illness; 1 to 2 , and 3 or more.

Neighborhood perception scales created by Friche et al. 17 were used to evaluate the physical and social environment. The neighborhood perception scales were constructed with the same database as this study and adapted to the individual level. Of the ten scales (Figure 1), aesthetic aspects, violence, physical disorder, social disorder, quality of services, and mobility had a statistically significant association with selfrated health; the number of items included in the scales ranged from 4 to 8 (see the Statistical Analysis and Results sections for further detail).

\section{Statistical analysis}

The scales for the perception of the physical and social environment developed by Friche et al. 17 at the census tract level were adapted for the individual level. The scores of the scales were estimated through principal components analysis (PCA); they ranged from 0 to 2.81. Lower scores reflected a worse perception of neighborhood characteristics, while higher scores were associated with a better perception. Four of the scales - participation, social cohesion, neighborhood problems and safety - were not considered due to a low intraclass correlation coefficient (ICC) 17. Cronbach's alpha value was used to assess the internal consistency of each scale, and showed a good to moderate consistency: the lowest Cronbach's alpha was 0.51 and the highest, 0.8317 .

The socioeconomic position score, also estimated by the principal components analysis, ranged between 0 and 3.39, and was later divided into quintiles. The higher the score, the better the socioeconomic position of the individual.

To assess the effect of the explanatory variables on self-rated health, ordered logistic regression, also known as proportional odds model, was used 25 . This regression model was selected because of the continuous nature of the original response variable, which had been grouped into ordinal categories, and assumed the proportional odds among these different categories 25 . The proportional odds assumption was assessed by means of the approximate likelihood-ratio test for ordinal response models proposed by Wolfe \& Gould ${ }^{26}$. The variables that presented a p-value $\leq 0.20$ in the univariate analysis were included in the multivariate analysis. The sampling design 


\begin{tabular}{|c|c|}
\hline AESTHETIC ASPECT & SAFETY \\
\hline $\begin{array}{l}\text { Your neighborhood: } \\
\text { 1. Has garbage and trash on the streets and sidewalks; } \\
\text { 2. Is pleasant for children; } \\
\text { 3. Is pleasant for youth and adolescents; } \\
\text { 4. Has trees that make the environment pleasant. }\end{array}$ & $\begin{array}{l}\text { In your neighborhood: } \\
\text { 1. You feel safe when walking at night; } \\
\text { 2. Violence is a problem. }\end{array}$ \\
\hline QUALITY OF SERVICES & PHYSICAL DISORDER \\
\hline $\begin{array}{l}\text { In your neighborhood, how do you rate the: } \\
\text { 1. Street lighting; } \\
\text { 2. Street and sidewalk maintenance; } \\
\text { 3. Public places for sports and leisure; } \\
\text { 4. Community facilities (...); } \\
\text { 5. Public transportation; } \\
\text { 6. Ease of obtaining high quality fresh food; } \\
\text { 7. Policing; } \\
\text { 8. Car traffic. }\end{array}$ & $\begin{array}{l}\text { Your neighborhood: } \\
\text { 1. Has buildings under constructions, or vacant lots or land; } \\
\text { 2. Is pleasant for children; } \\
\text { 3. Is pleasant for youth and adolescents; } \\
\text { 4. Has garbage and trash on the streets and sidewalks; } \\
\text { 5. Has vacant lots with trash and garbage; } \\
\text { 6. Has places where people play music at high volumes; } \\
\text { 7. People breaking windows, spraying graffiti or vandalizing property; } \\
\text { 8. How do you rate street lighting? }\end{array}$ \\
\hline MOBILITY & SOCIAL DISORDER \\
\hline $\begin{array}{l}\text { In your neighborhood: } \\
\text { 1. How do you rate the public spaces for sports and leisure; } \\
\text { 2. How do you rate car traffic; } \\
\text { 3. Are there stores within walking distance; } \\
\text { 4. Is it easy to walk around; } \\
\text { 5. You often see people walking around; } \\
\text { 6. You often see people exercising; } \\
\text { 7. You feel safe walking around during the day. }\end{array}$ & $\begin{array}{l}\text { Over the past } 12 \text { months, did you see or hear about: } \\
\text { 1. Prostitution in public places; } \\
\text { 2. People using illegal drugs in public places; } \\
\text { 3. People selling illegal drugs; } \\
\text { 4. Criminals or thieves walking in the neighborhood. }\end{array}$ \\
\hline SOCIAL PARTICIPATION & PROBLEMS IN THE NEIGHBORHOOD \\
\hline $\begin{array}{l}\text { People of the neighborhood organize to: } \\
\text { 1. Intervene in problems with others; } \\
\text { 2. Improve safety; } \\
\text { 3. Improve healthcare; } \\
\text { 4. Improve the appearance of the surroundings; } \\
\text { 5. Prevent dumping of trash; } \\
\text { 6. Prevent drug use; } \\
\text { 7. Demand better schools; } \\
\text { 8. Solve problems that affect the community. } \\
\text { Neighborhood residents participate in: } \\
\text { 9. Election campaigns; } \\
\text { 10. Protests; } \\
\text { 11. Elections for neighborhood associations. }\end{array}$ & $\begin{array}{l}\text { In your neighborhood: } \\
\text { 1. There is garbage or trash in the streets and on sidewalks; } \\
\text { 2. The noise bothers you; } \\
\text { 3. You feel safe walking during the day. } \\
\text { Over the past } 12 \text { months, you saw or heard about people: } \\
\text { 4. Breaking windows, spraying graffiti on the walls or vandalizing proprety; } \\
\text { 5. Using illegal drugs in public places; } \\
\text { 6. Selling illegal drugs; } \\
\text { 7. Cursing, insulting others; } \\
\text { 8. Being robbed on the streets of the neighborhood; } \\
\text { 9. Fighting, using firearms/guns; } \\
\text { 10. Being killed by guns; } \\
\text { 11. Being victims of sexual violence. } \\
\text { How do you rate: } \\
\text { 12. Street lightning; } \\
\text { around); } \\
\text { 14. Policing; } \\
\text { 13. Community facilities (accommodations, trash cans, ability to walk } \\
\text { 15. Public transportation; } \\
\text { 16. The walk to the closest stores. }\end{array}$ \\
\hline VIOLENCE & SOCIAL COHESION \\
\hline $\begin{array}{r}\text { In your neighborhood, have you seen or heard: } \\
\text { 1. Robbery; } \\
\text { 2. Fights; } \\
\text { 3. Death by handgun; } \\
\text { 4. Victim of sexual violence; } \\
\text { 5. Woman beaten by her husband; } \\
\text { 6. Child/adolescent beaten by a parent. }\end{array}$ & $\begin{array}{l}\text { Would you trust anyone in your neighborhood to: } \\
\text { 1. Leave your keys, if necessary; } \\
\text { 2. In an emergency, leave a member of your family; } \\
\text { 3. Lend things; } \\
\text { 4. Give advice if something bad happens; } \\
\text { 5. To help financially; } \\
\text { 6. Tell about job opportunities. }\end{array}$ \\
\hline
\end{tabular}

Note: adapted from Friche et al. 17. 
was specified in the analysis using the Stata survey prefix command svy.

The magnitude of the association was estimated by the odds ratio (OR) and its $95 \%$ confidence interval $(95 \% \mathrm{CI})$. The adequacy of the final model was verified by the likelihood-ratio test.

All statistical analyses were performed using version 12.0 of the Stata statistical software package (StataCorp LP, College Station, USA).

\section{Results}

A total of 4,048 adults participated in the study. Well over half $(59 \%)$ were women. Subjects ranged in age from 18 to 95 years (median: 43; Q1: 30 and Q3: 56). Just over half (53.2\%) were married or living together. In terms of schooling, $2.6 \%$ never attended school; $10.9 \%$ had a undergraduate/graduate degree. Most (57.7\%) had never smoked. The presence of at least one chronic illness was reported by $62.5 \%$, and only $12.4 \%$ of the interviewees reported having a motor, visual or hearing disability (Table 1).

In terms of self-rated health, $65.7 \%$ considered their health very good/good, $27.8 \%$ fair, and $6.5 \%$ poor/very poor.

Among the subjects who reported having good/very good health, $45.8 \%$ were in the higher (4th and $5^{\text {th) }}$ socioeconomic position score quintiles. For those who reported their health as very poor/ poor, $53.8 \%$ were in the lower (1st and 2 nd) socioeconomic position score quintiles.

The number of items included in the neighborhood perception scales ranged between 4 and 8. The lowest score was 0.00 and 2.81 the highest (Table 2). It was assumed that losses in each scale were at random.

Table 3 presents the results of the univariate analysis. All sociodemographic, economic, and health status variables were significantly associated with self-rated health. For instance, the OR for the variable sex was 1.38 (95\%CI: 1.16-1.64), which indicates that women have a $38 \%$ higher chance of reporting worse self-rated health than men.

Four perception scales of the physical and social environment had a statistically significant association with self-rated health: aesthetic quality, mobility, violence, and social disorder.

In the final model, after adjustment for potential confounding variables (Table 4), the subjects who self-rated their health as fair or poor/very poor, when compared to those who self-rated their health as very good/good, reported poor assessment of aesthetic aspects $(\mathrm{OR}=0.80$; 95\%CI: 0.68-0.94); their neighborhood having poor mobility $(\mathrm{OR}=0.78$; $95 \% \mathrm{CI}$ :
$0.64-0,96)$; poor quality of the available services $(\mathrm{OR}=0.84 ; 95 \% \mathrm{CI}: 0.71-0.98)$, and greater physical disorder $(\mathrm{OR}=0.83$; 95\%CI: 0.72-0.96) and social disorder (OR $=0.85$; 95\%CI: $0.74-0.98)$ in the neighborhood. The perception of violence was at the limit of statistical significance $(\mathrm{OR}=$ 0.86; 95\%CI: 0.74-1.00). The same magnitude of association was found when the poor/very poor self-rated health category was compared to the other categories.

To better understand how to interpret Table 4, let's examine Aesthetic Aspects as an example. Subjects who rated their own health as fair or poor/very poor when compared to those who rated their health as very good/good had a $20 \%$ greater chance of perceiving negative aesthetic aspects in their neighborhood.

\section{Discussion}

Our findings suggest that self-rated health is a complex multidimensional phenomenon tied up with one's perceptions about the place where he or she lives. Both the physical attributes of the neighborhood - which encompass aesthetics, the quality of services, and physical disorder and social attributes including violence, ease of mobility, and social disorder are associated with better or worse self-reported health, even when various potentially confounding individual level variables are taken into consideration.

By using the perception scales to gauge their neighborhood, it became evident that aspects of the physical and social environment impact self-rated health. The advantage of the neighborhood perception approach is that it captures information on particular features of the physical and social environment that cannot be obtained from the usual sources 16,17. There are, however, disadvantages; it can be more expensive, more time-consuming to conduct, and introduces the possibility of information bias 16,17 .

A positive perception of the physical and social environment is associated with better self- rated health, regardless of contextual and socioeconomic measures of the neighborhood and of the residents 19. Several mechanisms could explain this association: the perception of the physical and social environment may serve as mediator between socioeconomic position and self-rated health 16 . A poor perception of the physical and social environment may interfere with physical and psychological well being, triggering mechanisms that adversely affect one's health ${ }^{19}$. Finally, a favorable perception of the physical and social environment influences the adoption of healthy practices and behavior, such 
Table 1

Frequency distribution of selected variables according to the self-rated health of 4,048 adult. The BH Health Study, Belo Horizonte, Minas Gerais State, Brazil, 2008-2009.

\begin{tabular}{|c|c|c|c|c|}
\hline \multirow[t]{2}{*}{ Variables } & \multirow[t]{2}{*}{$n(\%)$} & \multicolumn{3}{|c|}{ Self-rated health [n (\%)] } \\
\hline & & Very good/Good & Fair & Poor/Very poor \\
\hline Age (years) * & $44.4(17.0)$ & $41(16.2)$ & $50(16.7)$ & $54.4(15.6)$ \\
\hline \multicolumn{5}{|l|}{ Sex } \\
\hline Male & $1,659(41.0)$ & $1,144(69,0)$ & $430(25.9)$ & $85(5.1)$ \\
\hline Female & $2,389(59.0)$ & $1,513(63.4)$ & $693(29)$ & $181(7.6)$ \\
\hline \multicolumn{5}{|l|}{ Marital status } \\
\hline Single & $1,214(30.0)$ & $913(75.2)$ & $253(20.9)$ & $47(3.9)$ \\
\hline Married, living together & $2,155(53.2)$ & $1,397(64.9)$ & $616(28.6)$ & $141(6.5)$ \\
\hline Divorced, separated & $333(8.2)$ & $192(57.7)$ & $108(32.4)$ & $33(9.9)$ \\
\hline Widow(er) & $346(8.6)$ & $155(44.8)$ & $146(42.2)$ & 45 (13.0) \\
\hline \multicolumn{5}{|l|}{ Schooling } \\
\hline No schooling & $105(2.6)$ & $40(38.1)$ & $37(35.2)$ & $28(26.7)$ \\
\hline $\begin{array}{l}\text { Able to read, primary school equivalency, } 1 \text { st- } 4 \text { th } \text { grades not } \\
\text { completed }\end{array}$ & $543(13.5)$ & $248(45.7)$ & $226(41.6)$ & $69(12.7)$ \\
\hline $1 \mathrm{st}-4$ th grade completed, 5 th-8th grade not completed & $982(24.2)$ & $540(55.0)$ & $358(36.5)$ & $83(8.5)$ \\
\hline 5th-8th grade completed, high school not completed & $632(15.7)$ & $442(70.0)$ & $158(25.0)$ & $31(5.0)$ \\
\hline High school graduate, technical school, attended university & $1,341(33.1)$ & $1,022(76.2)$ & $275(20.5)$ & $44(3.3)$ \\
\hline University graduate, post-undergraduate studies & $443(1.9)$ & $363(81.9)$ & $69(15.6)$ & $11(2.5)$ \\
\hline \multicolumn{5}{|l|}{ Chroic illness } \\
\hline None & $1,498(37.5)$ & $1,287(85.9)$ & $196(13.1)$ & $15(1.0)$ \\
\hline $1-3$ & $2,043(51.0)$ & $1,248(61.1)$ & $681(33.4)$ & $113(5.5)$ \\
\hline 3 or more & $460(11.5)$ & $101(22.0)$ & $229(49.8)$ & $130(28.2)$ \\
\hline \multicolumn{5}{|l|}{ Disabilities } \\
\hline No & $3,546(87.6)$ & $2,474(69.8)$ & $909(25.6)$ & $162(4.6)$ \\
\hline Yes & $502(12.4)$ & $183(36.5)$ & $214(42.7)$ & $104(20.8)$ \\
\hline \multicolumn{5}{|l|}{ Has private health insurance } \\
\hline Yes & $1,753(43.3)$ & $1,260(71.9)$ & 409 (23.3) & $83(4.8)$ \\
\hline No & $2,292(56.7)$ & $1,394(60.9)$ & $714(31.1)$ & $183(8.0)$ \\
\hline \multicolumn{5}{|l|}{ Smoking } \\
\hline Current smoker & $736(18.2)$ & $439(59.7)$ & $236(32.0)$ & $61(8.3)$ \\
\hline Former smoker & $976(24.1)$ & $588(60.4)$ & $308(31.6)$ & $78(8.0)$ \\
\hline Never smoked & $2,336(57.7)$ & $1,630(69.8)$ & $579(24.8)$ & $127(5.4)$ \\
\hline \multicolumn{5}{|l|}{ Consumes fruits and vegetables } \\
\hline$\geq 5$ times/week & $2,178(53.8)$ & $1,167(62.5)$ & $573(30.7)$ & $128(6.8)$ \\
\hline$<5$ times/week & $1,870(46.2)$ & $1,490(68.4)$ & $550(25.2)$ & $138(6.3)$ \\
\hline Body mass index $\left(\mathrm{kg} / \mathrm{m}^{2}\right)$ * & $26(5.0)$ & $25.4(4.8)$ & $27(5.3)$ & $28.5(5.9)$ \\
\hline \multicolumn{5}{|l|}{ Socioeconomic position (score) ** } \\
\hline 1 & $808(100)$ & $443(54.8)$ & $290(35.9)$ & $75(9.3)$ \\
\hline 2 & $818(100)$ & $92(60.2)$ & $260(31.8)$ & $66(8.0)$ \\
\hline 3 & $784(100)$ & $498(63.5)$ & $232(29.6)$ & $54(6.9)$ \\
\hline 4 & $804(100)$ & $573(71.3)$ & $190(23.7)$ & $41(5.0)$ \\
\hline 5 & $803(100)$ & $637(79.3)$ & $140(17.4)$ & $26(3.2)$ \\
\hline 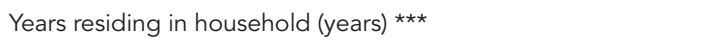 & $13(4-24)$ & $12(4-23)$ & $15(5-27)$ & $18(6-30)$ \\
\hline \multicolumn{5}{|l|}{ Perception of the neighborhood scales \# } \\
\hline Aesthetic quality & $1.3(0.66)$ & $1.3(0.65)$ & $1.2(0.66)$ & $1.0(0.70)$ \\
\hline Mobility & $2.0(0.46)$ & $2.0(0.45)$ & $1.9(0.47)$ & $1.8(0.53)$ \\
\hline Quality of services & $1.7(0.67)$ & $1.8(0.66)$ & $1.7(0.68)$ & $1.6(0.72)$ \\
\hline Violence & $1.7(0.67)$ & $1.7(0.66)$ & $1.6(0.69)$ & $1.5(0.64)$ \\
\hline Physical disorder & $1.8(0.70)$ & $1.8(0.69)$ & $1.8(0.71)$ & $1.7(0.70)$ \\
\hline Social disorder & $1.0(0.71)$ & $1.0(0.71)$ & $0.9(0.72)$ & $0.9(0.69)$ \\
\hline
\end{tabular}

* Mean and standard deviation;

** Score range between 0 and 3.39: higher number of assets = higher score;

*** Median, Q1 and Q3;

\# Score range between $0-2.81$ : better perception of neighborhood = higher score. The variable Quality of services had the most missing data: $\mathrm{n}=401$ ( $9.9 \%$ ) 
Description of the neighborhood perception scales. The BH Health Study, Belo Horizonte, Minas Gerais State, Brazil, 2008-2009.

\begin{tabular}{|c|c|c|c|c|c|}
\hline Scales & $\mathrm{n}$ & $\begin{array}{c}\text { Lowest } \\
\text { score }\end{array}$ & $\begin{array}{l}\text { Highest } \\
\text { score }\end{array}$ & $\begin{array}{l}\text { Mean } \\
\text { score }\end{array}$ & $\begin{array}{l}\text { Standard } \\
\text { deviation }\end{array}$ \\
\hline Aesthetic quality & 3,922 & 0 & 1.92 & 1.26 & 0.66 \\
\hline Mobility & 3,802 & 0 & 2.53 & 1.99 & 0.46 \\
\hline Quality of services & 3,647 & 0 & 2.81 & 1.76 & 0.67 \\
\hline Violence & 3,932 & 0 & 2.44 & 1.70 & 0.67 \\
\hline Physical disorder & 3,845 & 0 & 2.78 & 1.85 & 0.70 \\
\hline Social disorder & 3,655 & 0 & 1.99 & 1.00 & 0.72 \\
\hline
\end{tabular}

as physical activity, which have a positive impact on health 19 .

The scale which concerns the aesthetic aspect had higher scores when the individual's perception is positive about the green areas of their neighborhood, the lack of garbage or trash and pleasant places for children and youth. The quality of services scale had higher scores the better the individual evaluated the availability and efficiency of local public services. Both scales were positively associated with better self-rated health. Cummins et al. 27, when analyzing survey data from England and Scotland, reported that health is likely to be affected if the physical and social environment are perceived as being of low quality, as they limit the practice of physical activities, such as walking, sports, leisure, and increase stress due to insecurity. Wen et al. 28, in a study conducted in Cook County, Illinois, USA, also found that the perception of a neighborhood's physical and social characteristics and services as being of good quality is associated with better self-rated health, even when controlling for individual characteristics. The effect of the perception of one's neighborhood is partially explained by psychosocial factors, such as loneliness, depression, stress and hostility 28.

The mobility scale, which reflects the perception of the interviewee about ease of walking within the neighborhood, was associated with better self-rated health. It is plausible that a physical and social environment that encourages people's mobility, acting as a facilitator for the interaction among individuals and regular physical activity, has beneficial effects on health. Boclin et al. ${ }^{29}$, when estimating the association among the contextual variables of neighborhoods in Rio de Janeiro and physical and leisure activities found that physical and leisure activities were more frequent among residents of neighborhoods with higher human development indices (HDI). In Sweden, Jong et al. 30 report that the perception of better quality of green areas in the neighborhood was positively associated with three indicators of well being: regular physical activity, satisfaction with the neighborhood, and self-rated health.

The physical and social disorder scales were associated with self-rated health. Physical disorder is related to the deterioration of urban landscape, reflected by the presence of graffiti, vacant lots and vandalism. Social disorder relates to a behavior seen on the streets that is considered as a threat, such as prostitution, or use or sale of illicit drugs. The more individuals rated their perception of physical and social disorder as minimal, the better they self-rated their health.

It is possible that such an association comes from different mechanisms, causing health adverse effects, such as limited social relations, insecurity, difficulties of access to local services, and chronic stress. Hale et al. ${ }^{31}$ report that the perception of physical and social disorder, the presence of noise, dirt and crimes was associated with poor self-report health in adults in Texas, USA, even when controlling for lifestyle and sociodemographic characteristics. The authors suggest that the association they found is partially mediated by the poor quality of sleep 31 . A study conducted in Los Angeles, California, USA, found that the association between higher neighborhood disorder scores and worse self-rated health is explained by the perception of danger and poor social cohesion in the neighborhood 32 .

With regards to the violence scale, our results should be taken with caution, as the $95 \%$ CI we found was borderline (0.74-1.00). A possible explanation is that the scale used considered more severe types of violence, such as deaths by firearms, robberies, sexual abuse, and physical assault against women and children. 
Table 3

Odds ratio $(\mathrm{OR})$ and $95 \%$ confidence interval $(95 \% \mathrm{Cl})$ for selected variables according to self-rated health *. The $\mathrm{BH}$ Health Study, Belo Horizonte, Minas Gerais State, Brazil, 2008-2009.

\begin{tabular}{|c|c|c|}
\hline Variables & OR & $95 \% \mathrm{Cl}$ \\
\hline Age (years) & 1.03 & $1.03-1.04$ \\
\hline \multicolumn{3}{|l|}{ Sex } \\
\hline Male & 1.00 & \\
\hline Female & 1.38 & $1.16-1.64$ \\
\hline \multicolumn{3}{|l|}{ Marital status } \\
\hline Single & 1.00 & \\
\hline Married, living together & 1.86 & $1.50-2.31$ \\
\hline Divorced, separated & 2.21 & $1.57-3.11$ \\
\hline Widow(er) & 4.81 & 3.37-6.89 \\
\hline \multicolumn{3}{|l|}{ Schooling } \\
\hline No schooling & 1.00 & \\
\hline $\begin{array}{l}\text { Able to read, primary school equivalency, } 1 \text { st-4th grades not } \\
\text { completed }\end{array}$ & 0.52 & $0.29-0.93$ \\
\hline 1st- 4 th grade completed, 5 th- 8 th grade not completed & 0.34 & $0.19-0.60$ \\
\hline 5th-8th grade completed, high school not completed & 0.17 & $0.09-0.30$ \\
\hline High school graduate, technical school, attended university & 0.13 & $0.07-0.24$ \\
\hline University graduate, post-undergraduate studies & 0.08 & $0.04-0.15$ \\
\hline \multicolumn{3}{|l|}{ Chroic illness } \\
\hline None & 1.00 & \\
\hline $1-3$ & 3.80 & $3.05-4.73$ \\
\hline 3 or more & 19.6 & $14.01-27.4$ \\
\hline \multicolumn{3}{|l|}{ Disabilities } \\
\hline No & 1.00 & \\
\hline Yes & 4.92 & $3.90-6.20$ \\
\hline \multicolumn{3}{|l|}{ Has private health insurance } \\
\hline Yes & 1.00 & \\
\hline No & 1.60 & $1.35-1.90$ \\
\hline \multicolumn{3}{|l|}{ Smoking } \\
\hline Current smoker & 1.00 & \\
\hline Former smoker & 0.94 & $0.70-1.24$ \\
\hline Never smoked & 0.59 & $0.46-0.74$ \\
\hline \multicolumn{3}{|l|}{ Consumes fruits and vegetables } \\
\hline$\geq 5$ times/week & 1.00 & \\
\hline$<5$ times/week & 0.71 & $0.60-0.85$ \\
\hline Body mass index $\left(\mathrm{kg} / \mathrm{m}^{2}\right)$ & 1.03 & $1.03-1.04$ \\
\hline Socioeconomic position (score) & 1.07 & $1.05-1.10$ \\
\hline \multicolumn{3}{|l|}{1} \\
\hline 2 & 1.00 & \\
\hline 3 & 0.81 & $0.66-0.98$ \\
\hline 4 & 0.70 & $0.57-0.85$ \\
\hline 5 & 0.49 & $0.40-0.60$ \\
\hline Years residing in household (years) & 0.31 & $0.25-0.39$ \\
\hline Perception of the neighborhood scales ** & 1.01 & $1.00-1.02$ \\
\hline \multicolumn{3}{|l|}{ Aesthetic quality } \\
\hline Mobility & 0.84 & $0.72-0.97$ \\
\hline Quality of services & 0.72 & $0.59-0.88$ \\
\hline Violence & 0.89 & $0.77-1.01$ \\
\hline Physical disorder & 0.87 & $0.77-0.99$ \\
\hline Social disorder & 0.94 & $0.83-1.06$ \\
\hline Sex & 0.86 & $0.75-0.97$ \\
\hline
\end{tabular}

* Category of reference: Very good/Good; other categories: Fair; Poor/Very poor;

** Score ranging between 0 and 2.81: the better the perception of the neighborhood, the higher the score. 
Table 4

Self-rated health * for each of the neighborhood perception

scales ** in the final ordinal logistic regression model.

The BH Health Study, Belo Horizonte,

Minas Gerais State, Brasil, 2008-2009.

\begin{tabular}{lll}
\hline Scales & OR & $95 \% \mathrm{Cl}$ \\
\hline Aesthetic quality & 0.80 & $0.68-0.94$ \\
Mobility & 0.78 & $0.64-0.96$ \\
Quality of services & 0.84 & $0.71-0.98$ \\
Violence & 0.86 & $0.74-1.00$ \\
Physical disorder & 0.83 & $0.72-0.96$ \\
Social disorder & 0.85 & $0.74-0.98$ \\
\hline
\end{tabular}

95\% Cl: 95\% confidence interval; OR: odds ratio.

* Category of reference: Very good/Good;

** Score ranging between 0 and 2.81: the better the

perception of neighborhood, the higher the score.

Note: adjusted for: age (centered around the mean), civil

status, income score, sex, private health insurance, diseases,

body mass index (centered around the mean), presence of

disability, smoking, fruit and vegetable consumption, and

time of residence in household (centered around the mean).

It should be noted that by incorporating into the final model the variables that indicate the presence of chronic illnesses and disabilities, the OR lost statistical significance. More studies are necessary to better understand these results. A longitudinal study with adolescents in the United States reported that cumulative exposure to violence (witnessing armed violence, the threat of aggression, bullying, perception of insecurity, being a direct victim) was associated with a higher risk of poor self-rated health ${ }^{33}$. Subjects exposed to violence were 4.6 times more likely (95\%CI: 3.06-6.99) to self-report poor health, after controlling for demographic characteristics and family income 33 .

Some limitations should be mentioned. Other hierarchical levels of analysis were not considered. Contextual level variables about the places where people live and work were not included. This implies a limited understanding of the determinants of the illnesses in the individual and in populations, as context directly affects the individuals and their choices 34,35,36. Another limitation of the study is that its cross-sectional nature does not permit temporality to be addressed. Given that the use of subjective measures of the physical and social environment that may not correspond to objective aspects, such as the use of systematic social observation, information bias is possible. One additional limitation is that biological measures to characterize morbidities and to evaluate health were not available.

There are a number of advantages to this study. The sample included a large number of subjects: 4,048 adults that are representative of the population who lives in two of the nine public health districts of a large urban center located in a highly complex metropolitan area. In the planning of the study, several measures were taken to prevent possible biases; these included reliability assessments of the instruments used, the adoption of standardized procedures and equipment, exhaustive training of the field personnel, in addition to intense activities in the community to encourage participation in the study. These measures helped to insure the quality of the information collected and the internal validity of the study.

Finally, in our study, the perception of particular neighborhood attributes was associated with self-rated health, even considering different individual attributes. Even though the mechanisms responsible for these associations are not firmly established, the results indicate that public and health policies should include interventions that address the physical and social environment in addition to policies that focus on individuals.

This study highlights the need for more studies that address hierarchical levels other than the individual. Even though the magnitude the contextual effect on self-rated health is relatively smaller when compared to individual factors, its approach is still an important strategy to mitigate health inequalities. Compared to interventions centered on individuals, the development and implementation of prevention programs that focus on places/neighborhoods can impact the life of many people simultaneously and for longer periods of time 20,37 . 


\section{Resumen}

El objetivo de este estudio fue determinar la relación entre la percepción del lugar de residencia y la autopercepción de la salud. La información se obtuvo a través de entrevistas a 4.048 adultos que viven en Belo Horizonte, Minas Gerais, Brasil, entre 2008 y 2009. Para evaluar la asociación se utilizó la regresión logística ordinal. La autopercepción de la salud fue reportada como buena/muy buena, regular y mala/muy mala, respectivamente, por el 65,7\%, 27,8\% y 6,5\% de los participantes. Una mejor autopercepción de la salud se asoció con los siguientes aspectos del vecindario: la evaluación positiva de la estética y de la movilidad, la mejora de la calidad de los servicios locales, menos desorden físico y social. La percepción local de violencia mostró asociación estadística marginal con una mala autopercepción de salud. Los resultados mantuvieron el control de posibles variables de confusión demográficas, socioeconómicas, condiciones y conductas de salud. Los resultados indican que las políticas públicas y de salud deben incorporar intervenciones sobre el entorno físico y social, además de sobre las políticas de corte individual.

Autoevaluación; Estado de Salud; Percepción Espacial; Salud Urbana

\section{Contributors}

D. E. Rodrigues contributed to the conception of the study, data interpretation and writing of the article. C. C. César contributed to data analysis and interpretation, review and approval of the final version. C. C. Xavier contributed to review and approval of the final version. W. T. Caiaffa contributed to the conception of the study, results interpretation, and approval of the final version of the article. F. A. Proietti contributed to the conception of the project, data analysis, review and approval of the final version of the article.

\section{Acknowledgments}

The authors thank Professor Amélia Augusta de Lima Friche of the Federal University of Minas Gerais for her critical comments and suggestions. C. C. César and F. A. Proietti are fellows of the Conselho Nacional de Desenvolvimento Científico e Tecnológico (CNPq), Brazil.

\section{References}

1. Fylkesnes k, Forde OH. Determinants and dimensions involved in self-evaluation of health. Soc Sci Med 1992; 35:271-9.

2. Jylha M. What is the self-rated health and why does it predict mortality? Toward a unifed conceptual model. Soc Sci Med 2009; 69:307-16.

3. Fyers PM, Sprangers MAG. Understanding selfrated health. Lancet 2002; 359:187-8.

4. Benyamini Y, Leventhal EA, Leventhal H. Elderly people's ratings of the importance of health-related factors to their self-assessments of health. Soc Sci Med 2003; 56:1661-7.

5. Idler EL, Benyamini Y. Self-rated health and mortality: a review of twenty-seven community studies. J Health Soc Behav 1997; 38:21-37.
6. Strawbridge WJ, Wallhagen MI. Self-rated health and mortality over three decades: results from a time-dependent covariate analysis. Res Aging 1999; 21:402-16.

7. Lima-Costa MF, Cesar CC, Chor D, Proietii FA. Selfrated health compared with objectively measured health status as a tool for mortality risk screening in older adults: 10-year follow-up of the Bambuí Cohort Study of Aging. Am J Epidemiol 2011; 175:228-35.

8. Lima-Costa MF, Stepoe A, Cesar CC, De Oliveira C, Proietti FA, Marmot M. The influence of socioeconomic status on the predictive power of self-rated health for 6-year mortality in English and Brazillian older adults: the ELSA and Bambuí cohort studies. Ann Epidemiol 2012; 22:644-8. 
9. Debrand T, Pierre A, Allonier C, Lucas-Gabrielle V. Critical urban areas, deprived areas and neighbourhoods effects on health in France. Health Policy 2012; 105:92-101.

10. Stafford M, Martikainem P, Lahelma E, Marmot M. Neighbourhood and self-rated health: a comparision of public setor employees in London and Helsinki. J Epidemiol Community Health 2004; 58:772-8.

11. Verhaeghe PP, Tampubolon G. Individual social capital, neighbourhood deprivation, self-rated health in England. Soc Sci Med 2012; 75:349-57.

12. Tomey K, Diez Roux AV, Clarke P, Seeman T. Associations between neighborhood characteristics and self-rated health: a cross-sectional investigation in the Multi-Ethnic Study of Atherosclerosis (MESA) cohort. Health Place 2013; 24:267-74.

13. Chaskin R. Perspectives on neighborhood and community: a review of the literature. Soc Serv Rev 1997; 71:521-47.

14. Lebel A, Pampalon R, Villeneuve P. A multiperspective approach for defining neighbourhood units in the contexto of a study on heath inequality in the Quebec city region. Int J Health Geogr 2007; 6:27.

15. Proietti FA, Oliveira CL, Ferreira FR, Ferreira AD, Caiaffa WT. Unidade de contexto e observação social sistemática em saúde: conceitos e métodos. Physis (Rio J.) 2008; 18:469-82.

16. Shaefer-McDaniel N, Caugh MO, Campo PO, Gearey W. Examining methodological details of neighbourhood observations and the relationship to health: a review literature. Soc Sci Med 2010; 70:277-92.

17. Friche AAL, Diez-Roux AV, César CC, Xavier CC, Proietti FA, Caiaffa WT. Assessing the psychometric and ecometric properties of neighborhood scales in developing countries: Saúde em Beagá Study, Belo Horizonte, Brazil, 2008-2009. J Urban Health 2013; 90:246-61.

18. Bowling A, Barber J, Morris R, Ebrahim S. Do perceptions of neighbourhood environment influence health? Baseline findings from a British survey of aging. J Epidemiol Community Health 2006; 60:476-83.

19. Lucumí DI, Grogan-Kaylor A, Espinosa-García G. Asociación de la posición socioeconómica y la percepción del ambiente con la autopercepción del estado de salud en mujeres de Bogotá, Colombia. Rev Panam Salud Pública 2013; 34:14-20.

20. Poortiga W, Dunstan FD, Fone DL.Neighbourhood dreprivation and self- hated health: The role of perception of the neighbourhood and the housing problems. Health Place 2008; 14:562-75.

21. Observatório de Saúde Urbana de Belo Horizonte. http://www.medicina.ufmg.br/osubh (accessed on $03 /$ Jun/2014).

22. Gerência de Epidemiologia e Informação, Secretaria Municipal de Saúde de Belo Horizonte. Índice de vulnerabilidade à saúde. http://www.pbh. gov.br/smsa/biblioteca/gabinete/risco2003 (accessed on 05/Jun/2014).

23. Camargos VP, César CC, Caiaffa WT, Xavier CC, Proietti FA. Imputação múltipla e análise de casos completos em modelos de regressão logística: uma avaliação prática do impacto das perdas em covariáveis.Cad Saúde Pública 2011; 27:2299-313.
24. Célio FA, Xavier CC, Andrade ACS, Camargos VP, Caiaffa WT, Friche AAL, et al. Características individuais associadas à autopercepção da extensão territorial da vizinhança. Cad Saúde Pública 2014; 30:1935-46.

25. Abreu MNS, Siqueira AL, Caiaffa WT. Regressão logística ordinal em estudos epidemiológicos. Rev Saúde Pública 2009; 43:183-94.

26. Wolf R, Gold W. An approximate likelihood-ratio test for ordinal response models. Stata Technical Bulletin 1998; 42:24-27.

27. Cummins S, Stafford M, Macintyre S, Marmot M, Ellaway A. Neighbourhood environment and its association with self rated health: evidence from Scotland and England. J Epidemiol Community Health 2005; 59:207-13.

28. Wen M, Hawkleyb LC, Cacioppo JT. Objective and perceived neighborhood environment, individual SES and psychosocial factors, and self-rated health: an analysis of older adults in Cook County, Illinois. Soc Sci Med 2006; 63:2575-90.

29. Boclin KLS, Faerstein E, Ponce ACML. Características contextuais de vizinhança e atividade física de lazer: Estudo Pró-Saúde. Rev Saúde Pública 2014; 48:249-57.

30. Jong K, Albin M, Skärbäck E, Grahn P, Björk J. Perceived green qualities were associated with neighborhood satisfaction, physical activity, and general health: results from a cross-sectional study in suburban and rural Scania, southern Sweden. Health Place 2012; 18:1374-80.

31. Hale L, Hill TD, Burdette AM. Does sleep quality mediate the association between neighborhood disorder and self-rated physical health? Prev Med 2010; 51:275-8.

32. Bjornstrom EE, Ralston ML, Kuhl DC. Social cohesion and self-rated health: the moderating effect of neighborhood physical disorder. Am J Community Psychol 2013; 52:302-12.

33. Boynton-Jarrett R, Ryan LM, Berkman LF, Wright RJ. Cumulative violence exposure and self-rated health: longitudinal study of adolescents in the United States. Pediatrics 2008; 122:961-70.

34. Susser M, Susser E. Choosing a future for epidemiology: I. Eras and paradigms. Am J Public Health 1996; 86:668-73.

35. Diez-Roux AV. Bringing context back into epidemiology: variables and fallacies in multilevel analysis. Am J Public Health 1998; 88:216-22.

36. Marmot MG. Improvement of social environment to improve health. Lancet 1998; 351:57-60.

37. Yen IH, Syme SL. The social environment and health: a discussion of the epidemiologic literature. Ann Rev Public Health 1999; 20:287-308.

Submitted on $06 /$ Nov/2014

Final version resubmitted on $27 / \mathrm{Jan} / 2015$

Approved on 29/Jan/2015 